\title{
Comparative Study on Effect of P.P.C, Flyash Mixed O.P.C. \& Silica Fume Mixed O.P.C. on Concrete
}

\author{
Chetali Shrivastava \\ Civil Engineering Department, Sanghvi Institute of Management and Science, India
}

\begin{abstract}
Concrete is the most widely used construction material in all type of civil engineering works and cement is the main constituent of the concrete which act as a binder between fine and coarse aggregates. Mainly two types of cement that is ordinary Portland cement and Portland pozzolana cement are used, in which fly ash used as supplementary cementations material in the production of Portland cement concrete. A supplementary cementation material when used in conjunction with Portland cement, contributes to the properties of hardened concrete through hydraulic and pozzolanic activity or both. Pozzolana that is commonly used in concrete includes fly ash, silica fume and variety of natural pozzolanas such as calcinied clay and volcanic ash. Fly ash has been used in concrete at levels ranging from $10 \%$ to $30 \%$ by mass of the cementations material component. The project explore a theme on the use of fly ash and silica fume in different proportion and its potential use as site mix P.P.C Research is comprised of comparative study on effect of P.P.C. , fly ash mixed O.P.C. and silica fume mixed O.P.C on compressive strength of concrete of various grades. For the purpose, concrete cubes using factory mixed P.P.C. and Site mixed P.P.C were casted \& results of 7 and 28 days compressive strength were compared. Results of above experimental study demonstrate that site mix P.P.C concrete gives better strength for higher grade concrete up to $30 \%$ of fly ash replacement by cement and $10 \%$ of fly ash replacement for low grade concrete. Site mix P.P.C can be used as a replacement of factory mixed cement and which can proof as a economical cement.
\end{abstract}

Keywords: ordinary Portland cement, Portland pozzolana cement, compressive strength, Site mix P.P.C, Concrete

\section{Introduction}

Fly ash is used as a supplementary cementations material (SCM) in the production of Portland cement concrete. A supplementary cementations material, when used in conjunction with Portland cement, contributes to the properties of the hardened concrete through hydraulic or pozzolanic activity, or both. As such, SCM's include both pozzolans and hydraulic materials. A pozzolana is defined as a siliceous and aluminous material that in itself possesses little or no cementations value, but that will, in finely divided form and in the presence of moisture, chemically reacts with calcium hydroxide at ordinary temperatures to form compounds having cementations properties. Pozzolans that are commonly used in concrete include fly ash, silica fume and a variety of natural pozzolans such as calcined clay and shale, and volcanic ash. SCM's that are hydraulic in behavior include ground granulated blast furnace slag and fly ashes with high calcium contents (such fly ashes display both pozzolanic and hydraulic behavior). The potential for using fly ash as a supplementary cementitious material in concrete has been known almost since the start of the last century, although it wasn't until the mid-1900s that significant utilization of fly ash in concrete began following the pioneering research conducted at the University of California, Berkeley. The last 50 years has seen the use of fly ash in concrete grow dramatically with close to 15 million tons used in concrete. Historically, fly ash has been used in concrete at levels ranging from $15 \%$ to $25 \%$ by mass of the cementations material component. The actual amount used varies widely depending on the application, the properties of the fly ash, specification limits, and the geographic location and climate. Higher levels $30 \%$ to $50 \%$ ) have been used in massive structures (for example, foundations and dams) to control temperature rise. In recent decades, research has demonstrated that high dosage levels ( $40 \%$ to $60 \%$ ) can be used in structural applications, producing concrete with good mechanical properties and durability (Marceau 2002).Increasing the amount of fly ash in concrete is not without shortcomings. At high levels problems may be encountered with extended set times and slow strength development, leading to low early-age strengths and delays in the rate of construction. These drawbacks become particularly pronounced in cold-weather concreting. Also, the durability of the concrete may be compromised with regards to resistance to deicer-salt scaling and carbonation. For any given situation there will be an optimum amount of fly ash that can be used in a concrete mixture which will maximize the technical, environmental, and economic benefits of fly ash use without significantly impacting the rate of construction or impairing the long term performance of the finished product. The optimum amount of fly ash will be a function of wide range of parameters and must be determined on a case-by-case basis.

\section{Literature Review}

\section{Mini Soman1 Sobha.K}

Discussed to develop a concrete by replacement of Ordinary Portland Cement (OPC) with 50\% Fly Ash by mass. The fresh and hardened properties of High Volume Fly Ash Concrete (HVFAC) with 50\% replacement of cement and Ordinary Portland Cement Concrete (OPCC). The study discloses that high volume of Fly Ash in concrete reduces the water demand and improves the workability. Study also reveals that the OPCC and HVFAC exhibit similar hardened properties. Comparison of flexural response of beams made with OPCC and HVFAC with different percentage of reinforcement are also studied. It was observed that HVFAC 


\section{International Journal of Science and Research (IJSR) \\ ISSN (Online): 2319-7064}

Index Copernicus Value (2015): 78.96 | Impact Factor (2015): 6.391

beams have shown notable improvement in the deflection, cracking behavior and load carrying capacity.

\section{S. K. Malaviya, b. Chatterjee and k. K. Singh}

Discussed that fly ash is produced by thermal power plants while generating electricity by burning pulverized coal and is a waste material. In India, the availability of fly ash is substantial since the Indian coal contains as high as $40 \%$ ash much higher than the other countries. The disposal of this waste material is a matter of great concern from the environmental and ecological point of view. This paper is aimed to highlight the various applications of fly ash as building material such as lime / clay fly ash bricks, Portland Pozzolana Cement, light weight aggregates replacing the conventional building material to some extent.

\section{Syed afzal basha and p. Pavithra}

Discussed the Concrete is a vital ingredient in infrastructure development with its versatile and extensive applications. It is the most widely used construction material because of its mould ability into any required structural form and shape due to its fluid behavior at early ages. However, there is a limit to the fluid behavior of normal fresh concrete. Thorough compaction, using vibration, is normally essential for achieving workability, the required strength and durability of concrete. Inadequate compaction of concrete results in large number of voids, affecting performance and long-term durability of structures. Since due to the vast construction in the urban development programs there is a high demand of concrete in bulk and for achieving the requirement of concrete in bulk, fly ash is being used as a mineral admixture in concrete. Concrete mixes M25, M30, are designed as per the Indian standard code (IS-10262-82) by adding, $0 \%, 10 \%, 20 \%, 30 \%$ and $40 \%$ of fly ash. Concrete cubes of size $150 \mathrm{~mm}$ X $150 \mathrm{~mm} \mathrm{X} 150 \mathrm{~mm}$ are casted and tested for compressive strength at 7 days, 14 days, 21 days and 28 days curing for all mixes and the results are compared with that of conventional concrete

\footnotetext{
Michael Thomas

Discussed that fly ash is used as a supplementary cementations material (SCM) in the production of Portland cement concrete. A supplementary cementations material, when used in conjunction with Portland cement, contributes to the properties of the hardened concrete through hydraulic or pozzolanic activity, or both. As such, SCM's include both pozzolan and hydraulic materials. A pozzolana is defined as a siliceous or siliceous and aluminous material that in itself possesses little or no cementitious value, but that will, in finely divided form and in the presence of moisture, chemically reacts with calcium hydroxide at ordinary temperatures to form compounds having cementitious properties. Pozzolana that are commonly used in concrete include fly ash, silica fume and a variety of natural pozzolana such as calcined clay and shale, and volcanic ash. SCM's that are hydraulic in behavior include ground granulated blast furnace slag and fly ashes with high calcium
}

contents (such fly ashes display both pozzolanic and hydraulic behavior). Fly ash has been used in concrete at levels ranging from 15 to $25 \%$ by mass of the cementitious material component. The actual amount used varies widely depending on the application, the properties of the fly ash, specification limits, and the geographic location and climate. Higher levels (30\% to 50\%) have been used in massive structures (for example, foundations and dams) to control temperature rise.

\section{Methodology}

To achieve the objective of project following steps and procedure are followed during the experimental work in testing labs:

- Calculations of proportions to be used by Mix design

- Accumulation of materials

- Measurement of materials as per mix design

- Mixing of materials

- Casting of cube samples

- Marking of cube samples as per their specifications

- Curing of cube samples

- Testing of cube samples

- Maintaining test results of cube samples

- Comparison of test results on choosen parameters.

- Conclusion of the work as per results

\section{Results \& Discussion}

Following are the compressive strength results obtained after 28 days of curing for O.P.C ,FACTORY MIX P.P.C. AND SITE MIX P.P.C. i.e. ( F.A - $10 \%+$ SF- $5 \%$ ), ( F.A - $20 \%$ + SF- $5 \%$ ), ( F.A - 30\% + SF- $5 \%$ ) Concrete cube samples

Table: Comparison of 28 days compressive strength of O.P.C P.P.C \& site mix P.P.C.

\begin{tabular}{|c|c|c|c|c|}
\hline $\begin{array}{l}\text { Concrete } \\
\text { Grade }\end{array}$ & \begin{tabular}{|c} 
O.P.C \\
Concrete \\
Cube \\
Sample
\end{tabular} & \begin{tabular}{|c} 
Factory \\
Mix P.P.C \\
Concrete \\
Cube \\
Sample \\
\end{tabular} & $\begin{array}{c}\text { Site Mix P.P.C Concrete } \\
\text { Sample }\end{array}$ & Cube \\
\hline \multirow{3}{*}{ M-25 } & \multirow{3}{*}{26.69} & \multirow{3}{*}{29.13} & $($ F.A $-10 \%+$ SF- $5 \%)$ & 36.69 \\
\hline & & & (F.A $-20 \%+$ SF- $5 \%$ ) & 25.22 \\
\hline & & & $($ F.A $-30 \%+$ SF- $5 \%)$ & 17.07 \\
\hline \multirow{3}{*}{ M-30 } & \multirow{3}{*}{32.88} & \multirow{3}{*}{37.25} & $($ F.A $-10 \%+$ SF- $5 \%)$ & 37.59 \\
\hline & & & $($ F.A $-20 \%+$ SF- $5 \%)$ & 34.49 \\
\hline & & & $($ F.A $-30 \%+$ SF- $5 \%)$ & 32.13 \\
\hline \multirow{3}{*}{ M-35 } & \multirow{3}{*}{39.62} & \multirow{3}{*}{40.02} & $($ F.A $-10 \%+$ SF- $5 \%)$ & 39.34 \\
\hline & & & $($ F.A $-20 \%+$ SF- $5 \%)$ & 34.33 \\
\hline & & & $($ F.A $-30 \%+$ SF- $5 \%)$ & 29.16 \\
\hline \multirow{3}{*}{ M-40 } & \multirow{3}{*}{44.98} & \multirow{3}{*}{44.16} & $($ F.A $-10 \%+$ SF- $5 \%)$ & 58.79 \\
\hline & & & $($ F.A $-20 \%+$ SF- $5 \%)$ & 54.67 \\
\hline & & & (F.A $-30 \%+$ SF- $5 \%$ ) & 49.79 \\
\hline
\end{tabular}


International Journal of Science and Research (IJSR)

ISSN (Online): 2319-7064

Index Copernicus Value (2015): 78.96 | Impact Factor (2015): 6.391
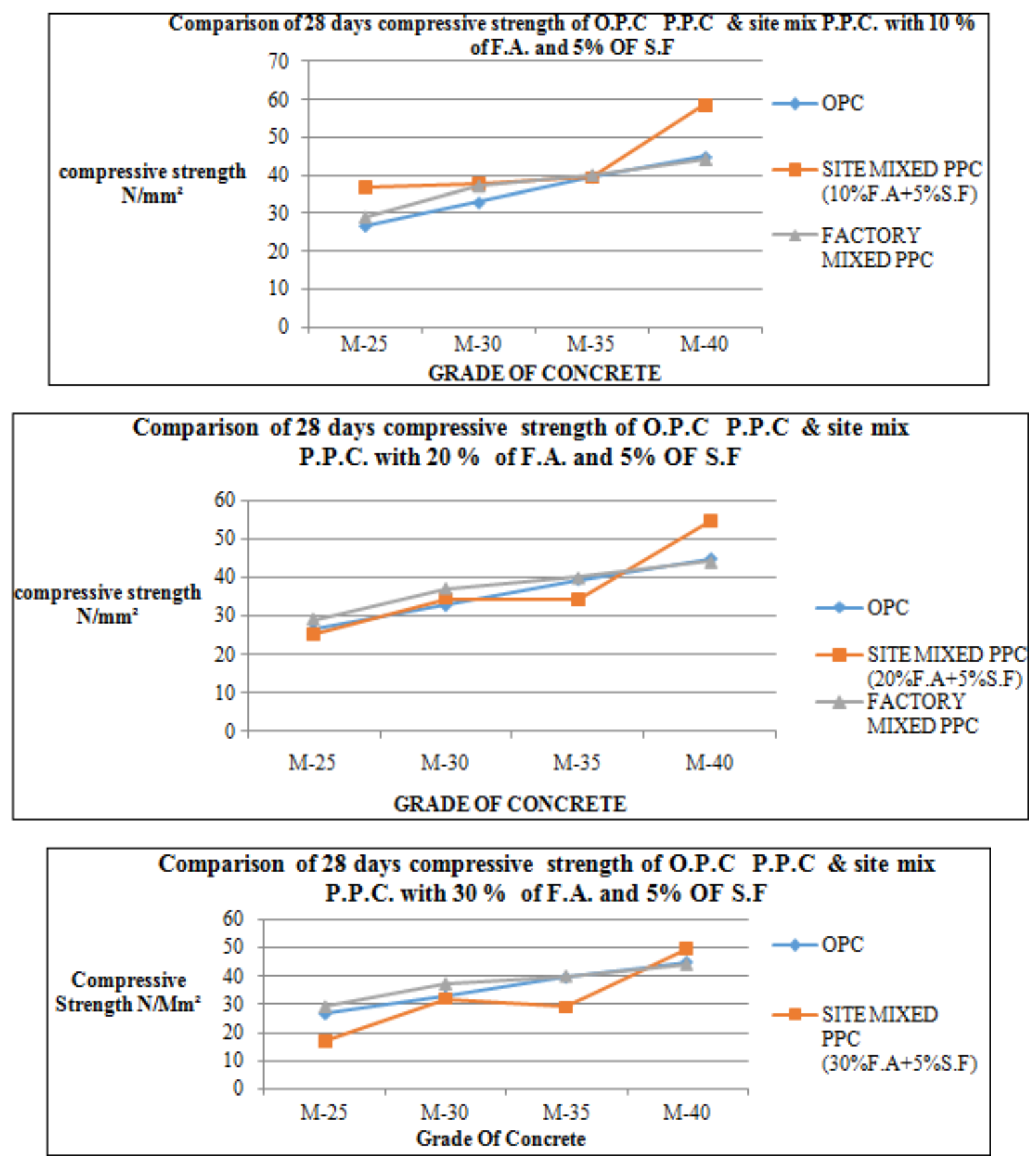

\section{Conclusion}

1) 1.Study on effect of P.P.C, Fly Ash mixed O.P.C and Silica Fume mixed O.P.C on concrete gave the conclusion that compressive strength of site mixed P.P.C concrete is higher than that of factory mixed P.P.C for higher grade concrete and lower in case of lower grade on concrete.

2) 2. Results also show that rate of gaining strength of normal O.P.C concrete is higher initially and gradually decreases with age of concrete. Whereas, factory mixed P.P.C concrete and site mixed P.P.C concrete gains strength slowly in initial period and goes on increasing with age of concrete.

3) 3. It is seen that up to $30 \%$ fly ash and $5 \%$ silica fume replacement with cement can be done for higher grade of concrete while for low grade concrete only $10 \%$ fly ash and $5 \%$ silica fume replacement can be done.
4) 4. In relative term it is seen that site mixed P.P.C will prove better as the concrete age and grade increases as compared to factory mixed P.P.C.

5) Result shows that factory mixed P.P.C. gives better strength for lower grade concrete.

6) According to result Site mix P.P.C will prove as economical cement as $30 \%$ replacement of cement by fly ash will reduce the cement cost and hence construction cost.

7) Site mixed P.P.C as replacement of factory mix P.P.C and normal O.P.C and gives a future scope for research on 90 days compressive strength performance of site mixed P.P.C

8) Overall it can be concluded that concept of sie mixed P.P.C can be accepted commercially and higher grade concrete can be made economically. 


\section{International Journal of Science and Research (IJSR) \\ ISSN (Online): 2319-7064}

Index Copernicus Value (2015): 78.96 | Impact Factor (2015): 6.391

\section{References}

[1] Mini Soman \& Sobha.K "Strength and Behaviour of High Volume Fly Ash Concrete', International Journal of Innovative Research in Science, Engineering and Technology Vol. 3, Issue 5, May 2014

[2] Sudarsana Rao.Hunchate1, Sashidhar.Chandupalle2, "Mix Design of High Performance Concrete Using Silica Fume and Super plasticizer" International Journal of Innovative Research in Science,Engineering and Technology Vol. 3, Issue 3, March 2014

[3] Debabrata Pradhan *, D. Dutta ** "Influence of Silica Fume on Normal Concrete" Int. Journal of Engineering Research and Applications www.ijera.com Vol. 3, Issue 5, Sep-Oct 2013, pp.79-82

[4] N. K. Amudhavalli1, Jeena Mathew2 EFFECT OF SILICA FUME ON STRENGTH AND DUR ABILITYPARAMETERS OF CONCRETE International Journal of Engineering Sciences \& Emerging Technologies, August 2012.

[5] Des King "THE EFFECT OF SILICA FUME ON THE PROPERTIES OF CONCRETE" 37th Conference on Our World in Concrete \& Structures 29-31 August 2012, Singapore

[6] Mr. Amol P. Titarmare "Experimental Study Report on Use of Fly Ash In High Grade Ready Mixed Concrete" International Journal of Scientific \& Engineering Research Volume 3, Issue 6, June-2012

[7] Mohammad Panjehpour1* "A REVIEW FOR CHARACTERIZATION OF SILICA FUME AND ITS EFFECTS ON CONCRETE PROPERTIES" International Journal of Sustainable Construction Engineering \& Technology (ISSN: 2180-3242) Vol 2, Issue 2, December 2011

[8] Prof. Vishal S. Ghutke1, Prof. Pranita S.Bhandari2 "Influence of silica fume on concrete" IOSR Journal of Mechanical and Civil Engineering (IOSR-JMCE) eISSN: 2278-1684, p-ISSN: 2320-334X PP 44-47

[9] S. K. MALAVIYA, B. CHATTERJEE "Fly ash - An emerging alternative building material", NMI, Jamshedpur1999, pp. 59-67 